\title{
Cities, states, and trust networks: chapter 1 of Cities and States in World History
}

\author{
Charles Tilly
}

Published online: 31 March 2010

(C) The Author(s) 2010. This article is published with open access at Springerlink.com

\begin{abstract}
An introduction to a vast but uncompleted survey of world history, this article argues that the study of the changing relationships among cities, states and trust networks can help us understand key elements of the emergence of our modern world. Beginning in ancient Uruk in modern-day Iraq, roughly five thousand years ago, the essay defines each of its central categories: city, state and trust network. It poses four questions to be pursued throughout the rest of the study. What determines the degree of segregation or integration of cities and states? What determines the relative dominance of cities and states? What determines the extent of separation or integration between cities or states, on one side, and trust networks on the other? What difference do these variable configurations make to the quality of ordinary people's lives?
\end{abstract}

The now-small Iraqi city of Al Warka lies about $300 \mathrm{~km}$ south of Baghdad, not far from where the joined Tigris and Euphrates rivers empty into the Persian Gulf. The Bible calls the place Erech, but five millennia ago local people knew it as Uruk. Within a few hundred years after 3600 BCE, it grew into a dynamic power center, a center of long-distance trade, and a religious magnet. At its height, Uruk was probably the world's largest city, with 50,000 inhabitants or more living in 6 square kilometers of walled area.

For centuries, rulers of Uruk dominated the area of southern Mesopotamia then called Sumer. As the city grew, hinterland populations abandoned peripheral settlements and moved closer to the dominant metropolis (Adams 1972, p. 739). City and hinterland taken together, Uruk has a claim to have been the world's first

Professor Charles Tilly passed away on 29 April 2008. Chris Tilly, his son, is the official contact for this paper.

C. Tilly $(\bowtie)$

c/o Chris Tilly, Institute for Research on Labor and Employment, UCLA,

Los Angeles, CA 90095-1478, USA

e-mail: tilly@ucla.edu 
substantial state. Some time between 2800 and 2500 BCE a great king named Gilgamesh ruled Uruk. Soon after Gilgamesh's time, the region's people were remembering him as a god and reciting visionary, often violent stories about him. Scribes eventually recorded those stories on clay tablets as different versions of the Gilgamesh epic.

In one version of the epic, Gilgamesh boasts about his city:

See if its wall is not as straight as the architect's string,

Inspect its...wall, the likes of which no one can equal;

Touch the threshold-stone-it dates from ancient times.

Approach the Enna Temple, the dwelling of Ishtar,

Such as no later king or many will ever equal.

Go up on the wall and walk around,

Examine its foundation, inspect its brickwork thoroughly,

Is not its masonry of baked brick,

Did not the Seven Sages themselves lay out its plans? (Postgate 1992, p. 73)

The first texts of the epic that archaeologists have-literally-unearthed date from around $2100 \mathrm{BCE}$, some 500 years after Gilgamesh actually ruled Uruk. The stories pit their flawed hero Gilgamesh against the anti-hero Enkidu, against the monster Humbaba, and against the avenging Bull of Heaven. At first, tyrannical, restless Gilgamesh behaves like a young punk, molesting Uruk's young women and attacking its young men. The gods answer Uruk citizens' exasperated prayers by sending a brutish giant, Enkidu, to check Gilgamesh's excesses. But Gilgamesh subdues wild man Enkidu. He does so not by means of armed combat, but by sending out the whore Shamhat to tame him. Shamhat seduces Enkidu, teaches him about civilization, and brings him into the city, where Gilgamesh and Enkidu wrestle to a draw, then form a fearsome alliance.

From their urban base, the heroes conquer enemies in the surrounding mountains and plains. They also go out to fetch great cedars for construction of Uruk's temples. When Gilgamesh spurns the goddess Ishtar, Uruk's protectress, Ishtar sends the Bull of Heaven to destroy Gilgamesh along with his city. He and Enkidu vanquish the magic bull and save Uruk, but the outraged gods condemn Enkidu to die. Gilgamesh wanders mourning his lost friend until he reaches the wise Utnapishtim in Dilmunmost likely today's Bahrain, in the Persian Gulf. The sage relates the story of a great flood remarkably like the Bible's later account of Noah's adventures. Utnapishtim then tells aging, grieving Gilgamesh about a plant that gives eternal youth. Gilgamesh dives into the sea, retrieves the plant, but loses it to a serpent. Disconsolate Gilgamesh returns to Uruk and dies.

The Gilgamesh epic, however mythical, lifts some of the heavy clouds that obscure the first emergence of cities and states. It emphasizes that cities and states first formed together: rulers based in substantial, socially differentiated, and commercially active settlements conquered hinterlands and drew on hinterland resources (remember those great cedars Gilgamesh and Enkidu fetched!) to reproduce their rule. It underlines the importance of religious claims for early rulers' legitimacy. Notably in the form of that massive wall, it dramatizes the constant threat of invasion and destruction by rebels from the hinterland or (more often) rival kings based in other cities. These distinctive features of early cities and 
states deserve our attention because now cities and states interact very differently. These days, cities and their surrounding states often struggle with each other, citysustaining resources typically come from across the world rather than from the cities' immediate surroundings, and few rulers of cities or states make serious claims to speak for the gods. No longer do states typically consist of a single city's grip on its hinterland.

The Gilgamesh epic also takes some unpacking that the ancient scribes did not provide. Implicitly, it distinguishes three kinds of connection between rulers and subjects, as well as among subjects: coercion, capital, and commitment. Coercion involves the threat or use of force, capital the deployment of goods and services, commitment the operation of ties that facilitate mutual recognition and coordination. The earliest cities and states would never have formed at all without substantial coercive connections; think of how young tough Gilgamesh treated his fellow citizens of Uruk. But no city or state can last long without renewing its supplies of goods and services, its capital. And some form of shared commitment connecting rulers with subjects as well as subjects with subjects - although not necessarily cults of living, jealous gods such as Ishtar-sustains every viable system of rule.

A system of rule is a set of social relations among subjects and between rulers and subjects that a) reinforce subjects' compliance to rulers' directives and b) reproduce relations between rulers and ruled. Both cities and states have their own systems of rule, sometimes closely coordinated, sometimes at swords' points with each other. Systems of rule vary from brutally authoritarian to gently democratic, but throughout the range reinforce compliance and reproduce ruler-ruled relations. Within systems of rule, we can usefully distinguish between relatively impersonal and relatively intimate connections among persons. For reasons that will become clear in a moment, I call the relatively intimate connections trust networks. One of this book's major themes stresses the crucial importance of trust networks for the texture and efficacy of systems of rule.

\section{A look across human history}

Cities and States in World History examines how cities, states, and trust networks have interacted during the five millennia for which we have clear evidence concerning the existence of cities and states. It spans from about the time of Gilgamesh to the present. Sketching and schematizing furiously, it leaps across continents and centuries in search of principles that help explain the enormous variation of cities, states, trust networks, and their interactions. It serves poorly as a sourcebook for detailed history. But it clarifies how and why momentous changes occurred. For changing relations among cities, states, and trust networks have caused some of the largest alterations in the quality of human life across the centuries.

If you need detailed histories of cities, states, or trust networks in one part of the world or another, you have generations of historians to choose from. Historian-critic Lewis Mumford, for example, wrote a magnificent series of urban panoramas, culminating in his The City in History (1961). For a long time, general histories in all parts of the world concentrated largely on states and their rulers (see, e.g., Finer 1997, Hall 1986). For the millennium after $990 \mathrm{CE}$, I have tried my own hand at a 
synthetic history of European states (Tilly 1992). Historians of war (e.g., Gat 2006; Glete 2002) inevitably center their accounts on states, which are both the chief executors and principal products of warfare. Histories of trust networks come thinner on the ground as such, but in the guise of kinship, long-distance trade, local solidarities, or religion often appear in general histories (see, e.g., Agulhon 1970; Curtin 1984; Marques et al. 2001; Pastor et al 2002; Raggio 1990; Wheatley 2001). The earlier the period, the thinner the available evidence concerning trust networks. Nevertheless, the value of seeing cities, states, and trust networks interact justifies the risk of stretching the evidence toward informed speculation.

In the timetables of human history, cities and states soon followed the invention of agriculture. The "invention of agriculture" means a shift to full-fledged, durable domestication of plants and animals as a way of life. So far as the archaeological record can tell us, that happened first in Southwest Asia, by around 8500 BCE. Along the Mediterranean's east coast, global warming caused a dramatic spread of wild grains after 12,000 BCE. Their abundance allowed hunter-gatherers to form more permanent settlements than before. Between 9000 and 8000 BCE, however, cold, dry weather reduced the availability of grain, inducing villagers to plant and cultivate field grains they had previously simply gathered. Then:

By 8000 [BCE], when conditions again became more favourable, these first farming communities had grown in size and number and they began to spread into other suitable areas. Initially these new economies combined cultivated cereals with wild animals, but around 7000 [BCE] domesticated sheep and goats began to replace gazelle and other wild game as the main source of meat (O’Brien 2002, p. 18).

All such dating is risky, for two reasons. First, subtle differences in definitions of agriculture (the first humanly controlled growth of plants? the full complement of farms, plants, and domesticated animals?) produce dating differences of a millennium or more. Second, new archaeology almost never pushes the dates of innovations forward, but regularly pushes them back. Nevertheless, all currently available estimates place the emergence of agriculture in Eurasia within a few thousand years after the global warming that almost certainly did occur around 12,000 BCE.

China had developed agriculture by 7500 BCE, the Indus Valley (most likely through diffusion from Southwest Asia) by 7000 BCE, New Guinea (most likely through independent invention) and Mesoamerica (surely by independent invention) likewise by 7000 BCE, then Egypt and Western Europe (diffusion!) after 6000 BCE (Diamond 1998, p. 100; Smith 1995, pp. 6-7; with some disagreement between the two). To be sure, any detailed chronology requires much more nuance. In Great Britain, for example, people started practicing mobile slash-and-burn agriculture with its temporary settlements widely around $4000 \mathrm{BCE}$, but did not often found permanent agricultural villages until about the time when metalworking spread toward 2500 BCE (Hayes 1993, pp. 41-52). Between the two dates, inhabitants of the British Isles began constructing ceremonial centers with their spectacular megaliths, of which Stonehenge provides the best known example (Pollard 2002).

In Britain and elsewhere, settled agricultural villages compounded into larger and more differentiated political units. The growth process proceeded rapidly, according 
to anthropologist Robert Carneiro; full-fledged states soon emerged (Carneiro 1994, p. 14). Cities formed initially as part of the same growth process. It happened first in the Middle East, but the rest of Eurasia and the Mediterranean did not lag far behind.

Cities are human settlements combining significantly denser resident populations than their surrounding territories, differentiation and inequality within the resident populations, some central authority, and nodal locations within extensive networks of communication. Because archaeological evidence leaves us to judge differentiation, inequality, central authority, and nodal locations from physical remains, we can't be sure when cities, thus defined, first appeared in human history. Jordan's Jericho, for example, had a concentrated settlement, substantial walls, and at least a thousand residents toward $7000 \mathrm{BCE}$. But Jericho could still have been essentially a large farming village. In that case, unlike Gilgamesh's formidable Uruk rampart, Jericho's early wall could have served mainly to protect stored crops from surrounding groups of hunter-gatherers or simply to keep out invading water (Gat 2006, pp. 170172; Smith 1995, p. 3).

Similarly, the excavated levels of Turkey's Chatal Huyuk site (from between 6859 and $6300 \mathrm{BCE}$ ) contain remarkably decorated rooms suggesting religious shrines as well as the remains of enough houses to accommodate 5,000 inhabitants. Yet the site does not yield enough other evidence of central authority, differentiation, inequality, or nodal location to qualify Chatal Huyuk unambiguously as a full-fledged city (Roaf 1990, pp. 43-46). Only after 4000 BCE, can we be confident that differentiated cities were operating and exerting wide-ranging power. Once they emerged, however, new city-builders could imitate the models established by their predecessors or try to improve on them. Gilgamesh boasted about the superiority of Uruk's city, wall, temple, and king to its predecessors and rivals.

Cities, then, first appeared in the same periods and regions as states. Like cities, states can only exist in symbiosis with agriculture that produces enough to support significant non-agricultural populations. Cities differ from strictly agricultural settlements, furthermore, by virtue of substantial populations, differentiated and specialized activities, and location as nodes in far-reaching networks of trade and political coordination. Cities and states maintain ambivalent relations: urban merchants and intellectuals seek the protection that states can provide, but resist the extraction and control that states' rulers impose on them. Rulers of states, on their side, commonly try to combat urbanites' independence, but also seek to benefit from concentrations of resources in cities as well as from the relative defensibility of compact cities as compared with scattered rural populations.

What of the state? A state is a structure of power involving four distinctive elements: 1) major concentrated means of coercion, especially an army, 2) organization that is at least partly independent of kinship and religious relations, 3) a defined area of jurisdiction, and 4) priority in some regards over all other organizations operating within that area. Although the four elements had existed separately for some time, no one put all four of them together before the Middle East's creation of both cities and states. No states existed anywhere in the world before 4000 BCE. By the era of Gilgamesh's Uruk, however, full-fledged cities and states were flourishing across significant parts of the Middle East, and possibly forming in other parts of Eurasia as well. Over the next millennium, states became 
permanent fixtures across much of Eurasia. Once they existed, furthermore, existing states provided models for emulation by other rulers and conquerors.

Then and now, cities and states vary in their relative emphasis on coercion, capital, and commitment. Predatory states such as Mongol empires of the thirteenth and fourteenth centuries CE got their way largely through the threat and use of armed force, as did Russian frontier fortress towns of the seventeenth century CE. The rich civilizations of South Asia's Indus Valley (roughly 2500-1900 BCE) left little trace of armies, but seem to have thrived on a combination of intensive trade and unifying culture. Although Italian city-states of the Renaissance usually backed their commercial enterprises with militias and mercenaries when necessary, their patrician merchants centered their connections with each other and their subjects on sizeable applications of capital.

Cities and states therefore vary in their relations to each other. Figure 1 sketches the most obvious of those variations: in dominance and integration. In some regions and eras, cities dominate states, either because the cities enjoy autonomous resources or because they subordinate states to their own priorities. Cities and surrounding states also vary from greatly segregated (little interplay between one and the other) to highly integrated (intensive interaction and mutual shaping between them). Four extreme types mark the limits of variation: autonomous cities, city-states, centralized states, and nomadic empires.

In our own time, the Vatican and Hong Kong represent something like autonomous cities despite their extensive external connections, Singapore operates more like a city-state within its compact hinterland, China counts as a formidable example of a centralized state, but nomadic empires have disappeared except for scattered remnants in Central Asia and East Africa. To trace cities and states in world history, then, is to examine change and variation in a given region's location within the space described by Fig. 1. With many a wiggle, the overall trend in city-state relations follows the arrow in the figure: from cities dominant to states dominant and (especially) from segregated to integrated. Later, however, we will see evidence that great cities such as Tokyo, London, and New York are now regaining some of the dominance they lost over most of history.

The inventions of cities and states enormously expanded human capacities for accumulation, innovation, and coordination. Cities created settings in which diverse

Fig. 1 Variable relations between cities and states

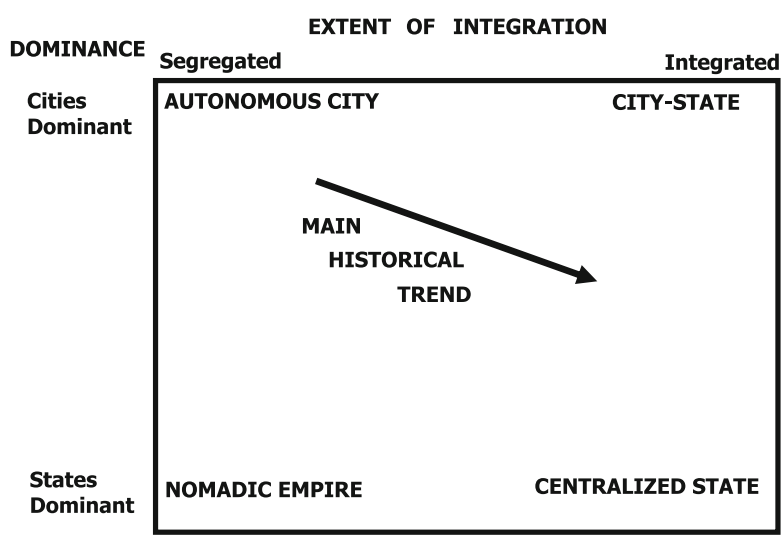


populations could interact without incessant warfare while connecting with their counterparts in distant locations. They promoted complementarities among human activities, and facilitated the production of collective goods such as secure public spaces and reliable supplies of water. States, on their side, established large zones in which people could move freely, exchange their goods, and even call on authorities to protect their property. Eventually they freed the bulk of humanity from living in small, closed, weapon-heavy population clusters. In these ways, cities and states multiplied human power for collective action.

They did so at a cost, sometimes a terrible cost. In cities, either rampant capital or flagrant coercion gave tycoons and rulers the means of imposing their wills on reluctant people who had contrary projects of their own and of subjecting inhabitants to living conditions more deadly and demoralizing than most hunters and gatherers had ever experienced. In states, arbitrary power and unwanted warfare intermittently devastated routine lives, substituting new, more massive forms of uncertainty and death for the daily struggles that beset every locality before the invention of states. In both cities and states, human experience felt the powerful effects of increasing scale.

\section{Trust networks}

Cities and states did not act alone. Every city and every state interacts with and to some extent depends on an ever-present form of commitment-maintaining connection: the trust network. Seen in two-person terms, trust is a relation in which at least one party places a valued enterprise at risk to the malfeasance, mistakes, or failure of another party. Trust is often, but not always, mutual; in the mutual case, Amy trusts Betty, while Betty also trusts Amy. Trust sometimes connects larger numbers of people who are carrying on some weighty, high-risk, long-term collective enterprise such as procreation, long-distance trade, political conspiracy, workers' mutual aid, or clandestine religious practice, and placing the enterprise at risk of members' malfeasance, mistakes, or failure.

When that happens, members can typically call on each other for aid on the simple basis of shared membership. In such a case, let us identify the connections among the members as a trust network. Trust networks existed across the world millennia before the emergence of cities and states, and significantly affected the operation of cities and states once cities and states emerged. Big-game hunting parties, kin groups, and (most likely) sworn brotherhoods, for example, all played significant roles in human life long before cities and states existed. In general, they qualified as trust networks.

Just as cities and states fall far short of exhausting or even representing all topdown structures of power-think of corporations, churches, and international organizations - trust networks form only one part of social life's bottom-up structure. Neighborhoods, communities, markets, voluntary organizations, and ethnic groups often contain or overlap trust networks, but rarely constitute them. In watching the interplay of cities, states, and trust networks, we are simply on concentrating on three distinctive forms of social organization whose interactions significantly affect the quality of human life. 
Like cities and states, trust networks vary in their relative emphasis on coercion, capital, and commitment: some punish defection with death, and others make defection unattractive by providing their faithful members with reliable incomes, even if all rely on substantial commitment, expressed in common languages, secret lore, distinctive communication lines, and other reinforcers of trust. Binding commitments can take the form of shared religion or ethnicity, trading ties, work-generated solidarities, communities of taste, and much more. They have the common property of promoting trust.

Over the long run of human history, trust networks, rather than cities, states, firms, churches, or other organizations, have formed the social basis for most weighty, high-risk, long-term collective enterprises (Tilly 2005). Ethnic trading networks, for example, have sustained long-distance trade from the origins of cities and states onward (Curtin 1984; Stein 1999). Only rarely and (on the whole) recently have such arrangements as social insurance and labor unions connected risky, valued, popular collective enterprises directly with cities and states. Indeed, prudent members of trust networks have generally tried to insulate them from predation or incorporation by cities and states.

Struggle between existing trust networks, on one side, and cities or states, on the other, has therefore gone on unceasingly, as for example when states try to conscript for military service young men who bear the hopes of their kin groups or when states seek to annihilate dissident religious sects. If we want to understand historical change and variation in cities and states, then, we have no choice but to take this distinctive form of organization - the trust network - seriously.

Despite great historical variation in the relative prominence of capital, coercion, and commitment as forms of connection, on the average cities, states, and trust networks each give greater emphasis to one of the three. Whatever else they do, states place significant weight on coercion. Cities serve as storehouses and headquarters for capital. Trust networks rely heavily on commitment: operation of ties that facilitate mutual recognition and coordination. To an important extent, encounters of cities, states, and trust networks therefore involve struggles for priority among capital, coercion, and commitment.

As later chapters of the book will show in detail, members of trust networks have historically engaged in those struggles by means of four main strategies: evasion, resistance, patronage, and integration. Evasion ranges from staying secret to dissimulating your character, masking your connections, and hiding your assets. Resistance, almost always dangerous, consists of confronting the capital and coercion of rulers or would-be rulers with forceful counter-claims. Resistance has often led to patronage, as powerful intermediaries have provided protection from rulers in return for tribute and loyalty.

Integration has occurred in two different ways: as members of trust networks (for example, conquering religions such as Islam) have become rulers themselves, and as leaders of trust networks have bargained, however asymmetrically, with rulers, for assured places in the system of rule. Twentieth-century totalitarian regimes forcibly integrated some trust networks into their systems of rule, but democratic regimes have also achieved some partial integration of trust networks through systems of social security and worker representation. Over the five millennia surveyed by this book, however, integration has rarely occurred. In general, relations between trust 
networks and rulers (whether of cities or of states) have taken the form of evasion, resistance, or patronage.

Cities and States in World History traces the dynamics of interaction among cities, states, and trust networks from the first traces of cities and states to the present. In a single small book, I have no hope of providing comprehensive descriptions of cities and states in all world regions across known human history. The long-term history of trust networks, furthermore, remains to be reconstructed and reported; I will simply refer to trust networks as part of my explanations for the operations of cities and states. Instead of providing a continuous chronicle of the world's cities, states, and trust networks, this book examines and explains essential features of variation and change of cities and states in four main regions-Asia, Africa, the Americas, and Europe - on the way to thinking about how interactions between cities and states have been changing in the contemporary era.

History has performed a rough but valuable natural experiment in relations among cities, states, and trust networks. Cities and states first emerged in Eurasia, including Europe, and within a thousand years or so all their major sites across the Eurasian land mass were communicating with each other. North and East Africa soon joined the same connected complex, followed much later by western, central, and southern Africa. On that side of the experiment, we have a history of extensive mutual influence. On the other side, the Americas provide a case of absolutely independent invention: even though the original human inhabitants of the Americas crossed the Bering Strait from Asia, we have no reason to think of America's pre-Columbian cities, states, or particular forms of trust networks as offshoots of their Eurasian counterparts. Meanwhile, New Guinea and other parts of the Pacific region where agriculture developed early have so far not yielded enough evidence on the long run of cities, states, and trust networks to permit their effective integration into the comparison. To a lesser degree, the same is true of western and southern Africa. Our strong comparison therefore sets off the Americas from Eurasia.

Moreover, it looks as though agriculture, cities, and states initially grew up independently in two separate American sites: central Mexico and the Andes. (Agriculture also seems to have begun independently in eastern North America, but without the subsequent independent development of substantial cities and states [Smith 1995]). Despite some earlier forays of Europeans across the North Atlantic to America, the Eurasian and American histories of cities, states, and trust networks proceeded in essential independence until European exploration and colonization began in 1492. Thus we can think of similarities in the initial emergence of cities, states, and trust networks in Eurasia and the Americas as stemming from parallel causal processes rather than from diffusion.

What processes? Radically simplified, they run like this:

Cities: accumulation and coordination of capital

States: accumulation and coordination of coercion

\section{Trust Networks: accumulation and coordination of commitment}

In each case, "accumulation" refers to an increase in sheer quantity, "coordination" to the approach toward a single connected set of interpersonal connections exerting collective control over the relevant activities. Cities depend on a region's 
passing of some threshold in the sheer quantity of available capital as well on the formation of a nucleus controlling a significant share of that capital. In parallel, states depend not only on the presence of substantial coercive means but also on concentration of a significant share of those means under the control of a bounded territorial organization. (Conversely, if coercive means multiply without coordination, small fighting bands multiply rather than states.) Likewise, trust networks require both the proliferation of risky relations (those in which persons are participating jointly in significant collective enterprises that are at risk to their participants' failures, mistakes, or malfeasance) and the creation of larger sets of interpersonal connections that exercise collective control over the enterprises.

Capital, coercion, and commitment reproduce themselves according to different logics. Capital renews itself through production of goods and services in sufficient abundance to provide for the next round of production. Cities reflect that reproductive cycle by nurturing institutions for the storage of capital: banks, warehouses, wealthy households, and more. Reproduction of coercion occurs through an openly competitive process in which wielders of coercive means use those means to deprive rivals and potential rebels of their own access to coercion. To the extent that coercive means involve expensive weapons, massive manpower, extensive food supplies, and substantial forms of transportation, to be sure, reproduction of coercion also entails sustained access to capital, either through direct application of coercion or through exchange of already accumulated wealth for coercive means. Reproduction of commitment proceeds in quite a different manner: via recruitment and birth. New members of trust networks arrive through person-by-person enlistment or through birth within households already belong to the network.

These differences in reproduction generate contradictions among the dynamics of capital, coercion, and commitment. Storage of capital offers incentives for coercionwielders to seize it for their own advantage, but the possession of capital allows capitalists to buy off coercionists and thus divert them from their pursuit of raw power. Person-by-person recruitment to webs of commitment operates less freely in the face of counter-pressures from coercion and capital. The relative dominance of capital, coercion, and commitment therefore creates marked variation in the qualities of ordinary people's lives.

In all three cases, other causal processes initiate the accumulation and coordination in question. As we have already seen, the growth of productive agriculture on a relatively large scale stands behind the emergence of both cities and states, just as the expansion of trade promotes the formation of cities. In the case of trust networks, initiating causes vary by type of network; they include the spread of religious cults, the growth of long-distance trade, growing opportunities for the placement of offspring, rising threats from neighboring populations, and (for crafts) intensifying competition or exploitation. All of them simultaneously increase threats to valued collective enterprises and the returns from increased coordination of such collective enterprises. These principles apply both to the vast web of Eurasian cities and states and to the spheres where cities and states emerged independently of the Eurasian experience, notably in the Americas.

History's natural experiment generated both similarities and differences. The more separate the cluster of cities and states, the more distinctive the patterns of cities, states, and trust networks. Through diffusion, interaction, and mutual modeling, cities, states, 
and trust networks of the vast Eurasian system acquired some common properties that set them in contrast to the long-isolated cities, states, and trust networks of the Americas. Zapotec areas of Central Mexico, for example, produced a strikingly distinctive pattern of mountaintop cities dominating adjacent valleys, grouping together ceremonial and administrative structures, but not specializing in commercial, agricultural, or craft activities (Marcus 2003, p. 358). Given that pattern, we can be fairly certain that their trust networks had distinctive properties as well.

Following the work of paleoanthropologists Joyce Marcus and Kent Flannery, Charles Mann describes Zapotecan civilization as one of four or five complexes that made the transition to cities and states during the second millennium BCE:

The Zapotec were based across the mountains from the Olmec, in Oaxaca's high Central Valley - three forty-to-sixty-mile-long bowls that intersect in a ragged Y. By about 1550 [BCE], they were abandoning the life of hunting and gathering to live in villages with defensive palisades. These early villages had wattle-and-daub houses, fine pottery, and some public architecture. They were controlled by "big men," the social scientist's term for the alpha male who is able in such informal settings to enforce his will through persuasion or force. Within a few hundred years, the big men acquired rank - that is, they began to wield power not only because of their personal charisma, but also because their societies had given them an elevated official position (Mann 2005, pp. 211-212).

Soon the whole region consolidated into three chiefdoms, each a state centered on a city. In Zapotec territory, agriculture rapidly led to accumulation and coordination of coercion, capital, and commitment.

\section{The silk road}

On the Eurasian continent, a much larger scale of accumulation and coordination had already developed two millennia earlier. The Silk Road illustrates the connectedness of the Eurasian system. The name Silk Road only dates from the Baron von Richtoven's writing about it in 1877 (Wood 2002, p. 9). By then, however, the phenomenon itself was already two thousand years old. From China's Han dynasty (206 BCE-220 CE) onward, that skein of east-west strands has carried precious goods, missionaries, and adventurers between eastern China and the Middle East, and thence into Europe. All strands counted, the Silk Road ran roughly from Chang'an (Xi'an) in northeastern China to Tyre and Antioch on the Mediterranean. In today's political terms, portions of the road transited China, Tajikistan, Kyrgyzstan, Uzbekistan, Turkmenistan, India, Pakistan, Iran, Iraq, Syria, and Lebanon, with offshoots into adjacent countries.

Although the conquests of Alexander the Great (334-323 BCE) included the western segment of the road, we should probably not speak of it as an East-West thoroughfare until early Han emperors began deliberately sending out mercantile missions as far as the Ferghana Valley (now in Uzbekistan and Kyrgyzstan) during the second century BCE. Soon after then, Chinese silk became a known and much admired commodity in Rome. Jade likewise traveled westward from China. Although the road brought many products into China from intermediate points, regions at and beyond the western terminus sent amber, pearls, red coral and, of all things, the chair 
(Wood 2002, pp. 85-86). Yet it took centuries before people at the road's eastern and western extremities had a clear idea of what lay at the other end.

In Antioch, where he finished his own long, dangerous journey from east to west, travel writer Colin Thubron described beliefs about the road two millennia earlier:

And still the Romans did not know the land the silks came from. Somewhere edging the easternmost sea, they heard, the country of the Seres escaped the influence of the stars, and was guided only by the laws of its ancestors. Mars never drove its people to war, nor Venus to folly. They had no temples, no prostitutes, no crimes, no victims. The king's women - seven hundred of themrode in golden chariots drawn by oxen. But this land of Serica, by some divine spell, was impossible to reach.

Meanwhile the Chinese, in mirror-image, came to believe that in a great city to the west-Rome, Alexandria or Constantinople - the people were ruled by philosophers, peacefully elected. Their palaces rose on crystal pillars, and they travelled in little white-draped carriages, and signalled their movements by the shaking of bells (Thubron 2007, p. 343).

Yet exchanges along the Silk Road eventually built up a steady stream of trade, and increasing mutual awareness. With many an interruption and deviation resulting from struggles for control of the territories between Rome and China, caravans have been plying the multiple silk roads in both directions ever since.

Technologies and beliefs likewise traveled the Silk Road. Gunpowder and Nestorians provide only two examples of the Silk Road's importance as a conduit. Gunpowder (probably invented in China during the ninth century CE) arrived first in Muslim lands and then in Europe between the eleventh and thirteenth centuries. By that time, Nestorian Christianity, a version of the faith originating in the Middle East, had been spreading in China for about six centuries. When European missionaries arrived to convert the Mongols or Chinese about the same time that gunpowder was heading west, they often encountered well established Nestorian priests and congregations. The reports of two 13th century CE European voyagers to the EastWilliam of Rubruck and Marco Polo-illustrate the large extent of Silk Road connections between East and West.

When Flanders-born Franciscan missionary William of Rubruck traveled to Karakorum, the Mongol capital, in $1254 \mathrm{CE}$, he encountered a number of Europeans, as well as an entrenched Nestorian priesthood, who looked like heretics to him. Of Karakorum itself, William reported:

There are two quarters in it; one of the Saracens in which are the markets, and where a great many Tartars gather on account of the court, which is always near this (city), and on account of the great number of ambassadors; the other is the quarter of the Cathayans [Chinese], all of whom are artisans. Besides these quarters there are great palaces, which are for the secretaries of the court. There are there twelve idol temples of different nations, two mahummeries [mosques] in which is cried the law of Machomet, and one church of Christians in the extreme end of the city. The city is surrounded by a mud wall and has four gates (Saad 2005, p. 89). 
At the time, Mongols controlled most of the territory from Moscow and Kiev south to Baghdad and east to Korea. They ran the largest contiguous land empire that has ever existed. Karakorum's profusion of coercion, capital, and trust networks reflected its position as a center of large-scale coordination, now facilitated by Mongol control of almost the entire Silk Road. Instead of building a tight perimeter around their conquered territories, the Mongols drew tribute from trade (Barfield 1989).

After Muslim expansion began in earnest during the seventh century CE, trading Europeans found themselves blocked from direct contact with the East. The rise of the Mongols gave traders new opportunities. By drawing on those opportunities, Marco Polo made himself Europe's most famous medieval traveler along the Silk Road. The irony is that even today we can't be sure how much of what Polo described he witnessed directly, how much he invented, and how much he pieced together from other travelers' tales. If we believe the stories he dictated to a fellowprisoner in 1298, however, he and his family made fabulous voyages to the East.

In 1298, Venice had once again gone to war against its great commercial rival, the city-state of Genoa. From the Venetian viewpoint, the war's worst moment arrived with the Battle of Korčula, a Dalmatian island controlled by Venice. After sacking Korčula, a Genoese fleet trounced its Venetian enemy and captured many galleys, including one outfitted and commanded by Marco Polo. The Genoese put Marco in prison, where a fellow captive, Rustichello, wrote down Marco's Description of the World, a mixture of memoir and travel guide. In his account, Marco offered vivid images of China's wealth and technical advancement over Europe. With wonder, he noted China's coal, paper currency, iron manufacturing, road networks, great canals, beautiful women, and magnificent cities.

Marco Polo's father and uncle had traveled widely in Persia and Central Asia. Then they had gone to the court of the great Mongol khan Qubilai (often called Kublai Khan), grandson of Genghis Khan. Drawing on Mongol legend, Marco wrote a surprisingly benign retrospective portrait of Genghis:

Some time after the migration of the Tartars to [Karakorum], and about the year of our lord 1162, they proceeded to elect for their king a man who was named Chingis-khan, one of approved integrity, great wisdom, commanding eloquence, and eminent for his valour. He began his reign with so much justice and moderation, that he was beloved and revered as their deity rather than their sovereign; and the fame of his great and good qualities spreading over that part of the world, all the Tartars, however dispersed, placed themselves under his command. Finding himself thus at the head of so many brave men, he became ambitious of emerging from the deserts and wildernesses by which he was surrounded, and gave them orders to equip themselves with bows, and such other weapons as they were expert at using, from the habits of their pastoral life. He then proceeded to render himself master of cities and provinces; and such was the effect produced by his character for justice and other virtues, that wherever he went, he found the people disposed to submit to him, and to esteem themselves happy when admitted to his protection and favour (Polo 2006, p. 81).

By the time that Marco's father and uncle met Qubilai, different groups of Mongols controlled a major chunk of Eurasia, and Qubilai's forces were conquering 
southern China as well. The elder Polos may have reached Changdu (Xanadu to later Europeans), the khan's summer capital, from 1264 onward. Qubilai asked the brothers to return home so they could encourage the pope to send back oil from the lamp at Jerusalem's Holy Sepulcher as well as a hundred men "acquainted with the Seven Arts" who would teach his people about Europe. As a safe conduct, the Polos carried a $30 \mathrm{~cm}$.long golden tablet from the khan, inscribed "By the strength of the eternal Heaven, holy be the khan's name. Let him that pays him not reverence be killed." It worked. They reached Italy safely in 1269 .

When the Polos set off again in 1271, 17-year-old Marco accompanied them. They originally planned to go east by ship from Hormuz on the Persian Gulf, a departure point for South and East Asia already well known to Arab seafarers. They abandoned that plan when they saw the leaky vessels that were supposed to carry them, "wretched affairs... only stitched together with twine made from the husk of the Indian nut." They shifted to an overland journey through Afghanistan, across Kashmir and Pamir, via the great Takla Makan desert, then along the steppe's southern edge back to Changdu.

The Polos traveled and traded widely in China, advised the khan, and accompanied him in his yearly migrations between Changdu and the khan's winter residence in Cambulac, later known as Beijing. On their return trip to Venice, they traveled by sea to Indochina, Indonesia, India, and back to Hormuz. They lost most of their accumulated riches when officials in the Byzantine state of Trebizond, at the southeast corner of the Black Sea, seized their goods. After seventeen years in China plus seven years of longdistance travel, the Polos reached Venice in 1295. By that time, 41-year-old Marco had spent more than half his life on his momentous Asian journey.

As of 1295, the Silk Road was dangerous, but thriving. It was connecting Asia's cities, states, and trust networks with those of Europe. The Mongols ran their own distinctive variety of state, but other formidable states intersected the path from Xi'an to Baghdad. Despite their origins as nomadic predators, the Mongols sustained and benefited from the long string of commercial cities that a thousand years of East-West interaction had built up along the Silk Road's broad path. European priests and merchants benefited from the long reach of their trust networks along the thoroughfare. By the thirteenth century $\mathrm{CE}$, Eurasian cities, states, and trust networks were interacting over vast distances. No one would then have mistaken Venice for Karakorum. Yet in some regards a connected Eurasian system of cities, states, and trust networks had formed. It extended into Africa as well as into the Indian and Pacific Oceans. After many mutations, it still exists today.

Fig. 2 Interactions of cities, states, and trust networks

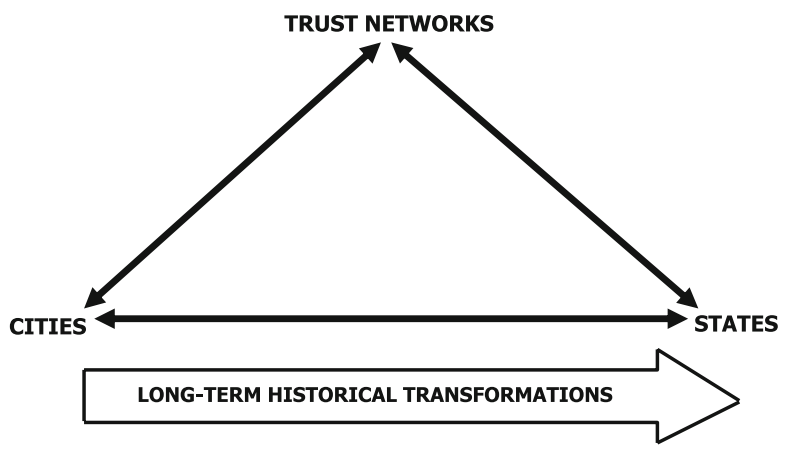


Both in Eurasia and elsewhere, the long-run historical story of cities, states, and trust networks features rising connectedness through ties of coercion, capital, and commitment. As the case of the Mongols has already suggested, fluctuations and reversals often occurred. But once European imperialism flourished during the fifteenth century $\mathrm{CE}$, increasing - and increasingly asymmetrical-connectedness prevailed. We live in an incomparably more connected and more unequal world than our ancestors of a thousand years ago.

Figure 2 schematizes the interactions and changes we are analyzing. Sometimes we concentrate on relations between trust networks and cities, sometimes on relations between trust networks and states, sometimes on relations between cities and states, and sometimes - but more rarely - on the whole triangular set of interactions. We are, furthermore, tracing long-term transformations in those interactions. Over the long run, we want to know how our incredibly connected world emerged from the oncefragmented relations among cities, states, and trust networks.

The process of fluctuating but finally increasing connection sets the problem for Cities and States in World History. The problem falls into four parts:

1. What determines the degree of segregation or integration of cities and states?

2. What determines the relative dominance of cities and states?

3. What determines the extent of separation or integration between cities or states, on one side, and trust networks, on the other?

4. What difference do these variable configurations make to the quality of ordinary people's lives?

Pursuing these four questions, the rest of my book will follow the Eurasian system and its American counterparts from early in history to the present. Chapter 2 provides an overview of cities, states, and trust networks from their origins onward. Chapters 3 to 6 close in successively on Asia, Africa, the Americas, and Europe. Chapter 7 considers cities and states in the age of capitalism. Finally, chapter 8 looks at the futures of cities, states, and trust networks in the light of their long, turbulent history.

Open Access This article is distributed under the terms of the Creative Commons Attribution Noncommercial License which permits any noncommercial use, distribution, and reproduction in any medium, provided the original author(s) and source are credited.

\section{Appendix: Contents as planned in 2008 for Cities and States in World History}

Preface

Chapter 1. Cities, States, and Trust Networks

Chapter 2. Historical Lives of Cities, States, and Trust Networks

Chapter 3. Asia

Chapter 4. Africa

Chapter 5. The Americas

Chapter 6. Europe

Chapter 7. Capitalism, Cities, and States

Chapter 8. Futures of Cities and States

References

Index 


\section{References}

Adams, R. M. C. C. (1972). Patterns of urbanization in early southern Mesopotamia. In M. J. Ucko, R. Tringham, \& G. W. Dimbledy (Eds.), Man, settlement and urbanism. Cambridge: Shenkman.

Agulhon, M. (1970). La vie sociale en Provence intérieure au lendemain de la Révolution. Paris: Société des Études Robespierristes.

Barfield, T. J. (1989). The perilous frontier, nomadic empires and China. New York: Blackwell.

Carneiro, R. L. (1994). War and peace: Alternating realities in human history. In S. P. Reyna \& R. E. Downs (Eds.), Studying war. Anthropological perspectives. Langhorne: Gordon and Breach.

Curtin, P. (1984). Cross-cultural trade in world history. Cambridge: Cambridge University Press.

Diamond, J. (1998). Guns, germs, and steel. The fates of human societies. New York: Norton.

Finer, S. E. (1997). The history of government from the earliest times. 3 vols. Oxford: Oxford University Press. Gat, A. (2006). War in human civilization. Oxford: Oxford University Press.

Glete, J. (2002). War and the state in early modern Europe. Spain, the Dutch Republic, and Sweden as fiscal-military states, 1500-1660. London: Routledge.

Hall, J. A. (Ed.) (1986). States in history. Oxford: Blackwell.

Hayes, A. (1993). Archaeology of the British Isles. New York: St. Martin's.

Mann, C. C. (2005). 1491. New revelations of the Americas before Columbus. New York: Knopf.

Marcus, J. (2003). A synthesis of the cultural evolution of the Zapotec and Mixtec. In K. V. Flannery \& J. Marcus (Eds.), The cloud people. Divergent evolution of the Zapotec and Mixtec civilizations. Clinton Corners: Percheron Press. revised edition.

Marques, M. M., Santos, R., \& Araújo, F. (2001). Ariadne's thread: Cape Verdean women in transnational webs. Global Networks, 1, 283-306.

Mumford, L. (1961). The city in history. Its origins, its transformations, and its prospects. New York: Harcourt, Brace \& World.

O’Brien, P. K. (Ed.) (2002). Oxford atlas of world history. Oxford: Oxford University Press.

Pastor, R., Pascua, E., Rodríguez-López, A., \& Sánchez-León, P. (2002). Beyond the market. Transactions, property and social networks in monastic galicia 1200-1300. Leiden: Brill.

Pollard, J. (2002). Neolithic Britain. Princes Risborough: Shire Publications.

Polo, M. (2006). The travels of Marco Polo. New York: Cosimo Classics.

Postgate, J. N. (1992). Early Mesopotamia. Society and economy at the Dawn of History. London: Routledge.

Raggio, O. (1990). Faide e Parentele. Lo Stato Genovese visto dalla Fontanabuona. Turin: Einaudi.

Roaf, M. (1990). Cultural atlas of Mesopotamia and the Ancient Near East. New York: Facts on File.

Saad, R. (Ed.) (2005). William of Rubruck's account of the Mongols. Rockville: the editor.

Smith, B. D. (1995). The emergence of agriculture. New York: Scientific American Library.

Stein, G. J. (1999). Rethinking world-systems. Diasporas, colonies, and interaction in Uruk Mesopotamia. Tucson: University of Arizona Press.

Thubron, C. (2007). Shadow of the Silk Road. New York: HarperCollins.

Tilly, C. (1992). Coercion, capital, and European states, 990-1992. Oxford: Blackwell. Revised edition. (2005), Trust and rule. Cambridge: Cambridge University Press.

Tilly, C. (2005). Trust and rule. Cambridge: Cambridge University Press.

Wheatley, P. (2001). The places where men pray together. Cities in Islamic Lands seventh through the Tenth Centuries. Chicago: University of Chicago Press.

Wood, F. (2002). The silk road. Two thousand years in the heart of Asia. Berkeley: University of California Press.

Charles Tilly (1929-2008) held faculty appointments at Delaware, Harvard, Toronto, Michigan, and the New School University, and finished his career as the Joseph L. Buttenwieser Professor of Social Science at Columbia University. His work focused on large-scale social change and its relationship to contentious politics, especially in Europe since 1500 . His over 50 books and monographs included a number quite relevant to the essay in this issue, such as An Urban World (1974), The Formation of National States in Western Europe (1975), Coercion, Capital, and European States, A.D. 990-1990 (1990), Cities and the Rise of States in Europe, AD 1000-1800 (1994), Expanding Citizenship, Reconfiguring States (1999), Trust and Rule (2005), and Democracy (2007). Tilly served as Senior Editor of Theory and Society for many years. A member of the National Academy of Sciences, the American Academy of Arts and Sciences, the American Philosophical Society, and the Ordre des Palmes Académiques, he received numerous international prizes and honorary degrees. 